一技術報告一

固相分散抽出一GC/MS 法によるヒト血清中合成カンナビノイドの分析法の検討

\author{
阿久津 守 $^{1}$ ，杉江謙一1，斎藤貢一2 \\ 1厚生労働省関東信越厚生局麻薬取締部・鑑定課 \\ 干102-8309 東京都千代田区九段南 1-2-1 九段第三合同庁舎17階 \\ 2星薬科大学薬品分析化学教室 \\ 干142-8501 東京都品川区荏原 2-4-41
}

\title{
Examination of analytical method for synthetic cannabinoids in human serum by solid-phase dispersive extraction-GC/MS
}

\author{
Mamoru Akutsu ${ }^{1}$, Ken-ichi Sugie ${ }^{1}$ and Koichi Saito ${ }^{2}$ \\ ${ }^{1}$ Narcotics Control Department, Kanto-Shin'etsu Regional Bureau of Health and \\ Welfare Ministry of Health, Labour and Welfare \\ 1-2-1, Kudan-Minami, Chiyoda-ku, Tokyo, 102-8309, Japan \\ ${ }^{2}$ Department of Analytical Chemistry, Faculty of Pharmaceutical Sciences, Hoshi University \\ 2-4-41, Ebara, Shinagawa-ku, Tokyo, 142-8501, Japan
}

(Received 10 April 2015; accepted 31 August 2015;

Published online 30 September 2015 in J-STAGE DOI: 10.3408/jafst.703)

In order to prove synthetic cannabinoid abuse, it is necessary to detect intact synthetic cannabinoids or their metabolites from such biological samples as urine or blood. Generally, blood is used as the biological sample because it is usually difficult to detect intact synthetic cannabinoids in urine. Furthermore, a rapid and accurate method for the detection of synthetic cannabinoids in the biological sample is required. Therefore, we examined the applicability of solid-phase dispersive extraction (SPDE)-GC/MS in the rapid detection of intact synthetic cannabinoids in blood. We chose seven synthetic cannabinoids designated as narcotics. To determine the optimum operating conditions for SPDE, we selected Oasis ${ }^{\circledR}$ HLB as the solid-phase material for pre-treatment and filled it with $10 \mathrm{mg}$ into the equipment, and acetone as the eluent. The pre-treatment resulted in $80-100 \%$ recovery. Furthermore, the pre-treatment time was significantly reduced in SPDE compared to solid-phase extraction (SPE). In addition, the pre-treatment protected operators from unnecessary exposure, reduced cross-contamination of chemicals, and decreased operation complexity. The limit of detection $(\mathrm{S} / \mathrm{N}>3$ ) of JWH-018, JWH-122, cannabicyclohexanol $(\mathrm{CCH}), \mathrm{XLR}-11$, and AM2201 was $2.5 \mathrm{ng} / \mathrm{mL}$, and that of JWH-073 and MAM-2201 was $5 \mathrm{ng} / \mathrm{mL}$. The limit of quantification $(\mathrm{S} / \mathrm{N}>10)$ of $\mathrm{JWH}-018$, JWH-122, CCH, XLR-11, and AM2201 was $5 \mathrm{ng} / \mathrm{mL}$, and that of JWH-073 and MAM-2201 was $10 \mathrm{ng} / \mathrm{mL}$. The average recoveries of the seven synthetic cannabi- 
noids from pooled serum samples spiked at 25 and $450 \mathrm{ng} / \mathrm{mL}$ were $76.9-107.4 \%$ (SD: 6.4-10.7\%) and 63.1-89.6\% (SD: 3.9-8.2\%), respectively. (SPDE)-GC/MS was proven to be a useful method for detecting intact synthetic cannabinoids in blood.

Key words: SPDE, GC/MS, synthetic cannabinoid

\section{緒 言}

大麻の精神作用成分であるテトラヒドロカンナビ ノールと類似の作用を示す合成カンナビノイド類を 乾燥植物細片に混合したもの（いわゆる危険ドラッ グ）が，2004年以降世界各国に広がり，我が国にお いても「お香」などと標榜して販売されており，健 康被害が急増している ${ }^{1,2)}$. 当該合成カンナビノイ ドについては，新たに出現するたびに順次「指定薬 物」に指定されており，また依存性，精神毒性等が 確認された物質については麻薬に指定され，一層厳 格に規制されている3 ${ }^{3}$.さらに，平成26年 4 月の薬 事法改正により，指定薬物に指定されたものは，使 用罪の適応を受けることになった。使用罪を立証す るためには，尿や血液などの生体試料から指定薬物 成分または代謝物を検出することが肝要となる。こ の際，生体試料から未変化体成分が検出されること が望ましいが，一般に合成カンナビノイド類は，尿 中から未変化体の成分を検出することが困難であ り4,5)，未変化体を捕らえるためには，血中からの 検出が主に行われている6,7). また生体試料の鑑定 試験は迅速かつ正確さが要求される，そこで，本研 究においては, 合成カンナビノイド類の中でも指定 薬物より使用罪の罰則規定が厳しい麻薬に格上げ指 定されたFig. 1 に示す 7 品目（JWH-018，JWH122，JWH-073，カンナビシクロヘキサノール (CCH)，XLR-11，AM2201，MAM-2201）に着目 し，血中未变化体の迅速検出法の検討を行うことと した。

従来, 血液等生体試料の前処理には固相抽出法 (Solid-phase extraction; SPE) が沉用されており， 当該方法は, 液一液抽出と比較して，1）使用する溶 媒が少量，2)エマルジョンが生成されないこと，3）

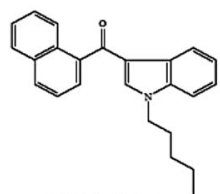

JWH-018

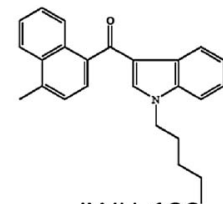

JWH-122

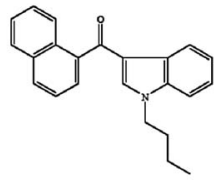

JWH-073

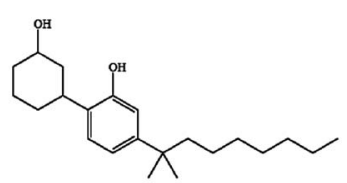

Cannabicyclohexanol (CCH)<smiles>[Y14][R11]([H])(C)CCCC1CCCC2C1CC2C(C)C(C)(C)C</smiles><smiles>CCCCC1CCCC1CC(C)c1cccc2ccccc12</smiles>

AM2201

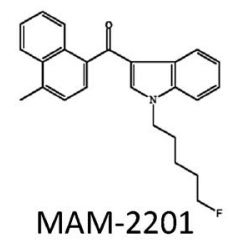

Fig. 1 Chemical structures of seven synthetic cannabinoids.

多数試料の処理が迅速などのメリットがあるが，他 方，SPE は，開放系で処理が行われるため，有害 化学物質による実験者への曝露やクロスコンタミ ネーションなどが危惧される．特に薬物乱用者は注 射器の共用などから肝炎ウイルスや HIV 感染者な ぞも多く, 当該感染者の血液については慎重に取扱 う必要があり，実験中の血液飛散等がないよう配慮 しなければならないが，SPEで主に使用するマニ ホールドのような開放系の器具などから感染する盧 も無視できない。そこで本研究では，前述の問題改 善と試験の迅速化を図ることを目的として固相分散 抽出法 (Solid-phase dispersive extraction; SPDE) を採用し，その有用性を検討した。 また従来，一般 に合成カンナビノイド類の血液等生体試料の検出 は，比較的感度の良い LC / MS 等で行われている が6-11), 法科学分野では, 原理の違う複数の技法に 
よる分析を実施することが推奨される12)ことから， $\mathrm{LC} / \mathrm{MS}$ 等とは別に GC/MS による分析法を検討す ることとした。

なお，SPDEとは，マイクロチューブ内におい て，試料液中に固相抽出剤を分散させ，これを遠心 ろ過フィルターを用いて，1）遠心分離により固相 と溶媒相をろ別，2）分散洗浄，3）分散溶出，の3 ステップ操作を行うもので，既存のSPEの欠点を 克服した抽出およびクリーンアップ方法であり，血 清中のベンゾジアゼピン系薬物やバイコマイシンの 検出に応用されている13,14)。本研究では，血清を試 料として前記の合成カンナビノイド類について測定 を行い，SPDEの適用性を検討した。

\section{材料および方法}

\section{1 試料および試薬}

凍結ヒト血清は，提出者から適切な同意が得ら れ，個人情報が確実に連結不可能で匿名化されてい る旨の証明が得られたものをコスモ・バイオ侏から 購入した。 JWH-018, JWH-073, JWH-122, AM2201，MAM-2201 およびXLR-11は Cayman Chemical 社から麻薬指定前に購入した. $\mathrm{CCH}$ は, 麻薬指定前に国立医薬品食品衛生研究所より提供を 受けたものを使用した。 その他の試薬は試薬特級品 を関東化学株式会社から購入した。

\section{2 器具および装置}

器具

SPDE で使用する遠心ろ過フィルター（製品名： （引過 $\left.{ }^{\mathrm{M} M}\right)$ およびスクリューバイアル（製品名： キャップチューブTM) は(侏)フロンティア・サイエ ンスから提供されたものを使用した（Fig. 2). 固 相抽出剂にはOasis ${ }^{\circledR}$ HLB $(30 \mu \mathrm{m})$ を用い, Oasis ${ }^{\circledR}$ HLBが充填されたカートリッジは Waters 社から購 入した. $2 \mathrm{~mL}$ のマイクロチューブはワトソン株式 会社から購入した.

\section{装置}

卓上遠心機: H-36(侏)コクサン, 超音波洗浄機： VS-F100アズワン(侏), 高速パラレル濃縮装置 : TurboVapLV バイオタージ・ジャパン侏)，パーソナル 遠心機：CHIBITAN II（10 krpm）メルク(株)

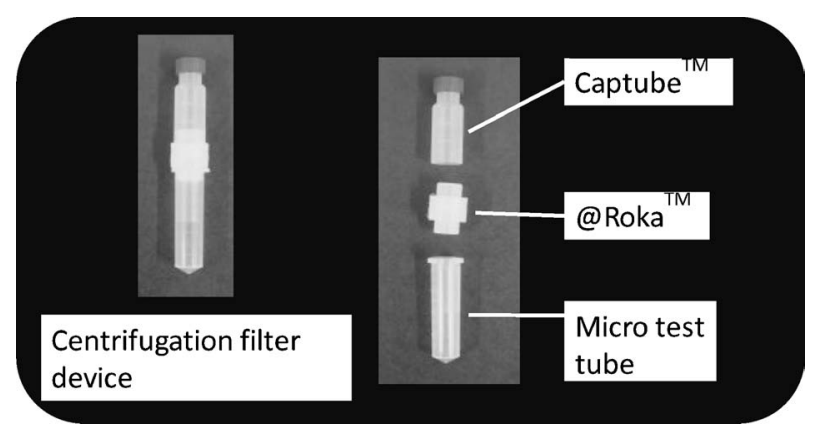

Fig. 2 Photograph of centrifugation filter device used for SPDE.

\section{3 固相懸濁剂の調製}

Oasis ${ }^{\circledR}$ HLB カートリッジから取り出した固相剂 $100 \mathrm{mg}$ をマイクロチューブに入れ，メタノール 1.0 $\mathrm{mL}$ を加えた。このマイクロチューブに@ろ過 $\mathrm{TM}$ 装着し，フィルター反対側（上部）にも同様にマイ クロチューブを装着した. Oasis ${ }^{\circledR}$ HLB を添加した マイクロチューブが下側に位置したままボルテック スミキサーを用いて擋拌し, 固相剤をメタノール中 に分散させた. 直ちにカートリッジを上下逆にして 遠心分離 $(3,000 \mathrm{rpm}, 1 \mathrm{~min})$ し, 溶媒をろ別した。 溶媒が入ったマイクロチューブを外し, 代わって超 純水 $1.0 \mathrm{~mL}$ を入れたマイクロチューブを@ろ過 ${ }^{\mathrm{TM}}$ に装着し, 再び上下逆 $\left(\mathrm{Oasis}^{\circledR}\right.$ HLB を添加したマ イクロチューブを下向き）にして遠心分離（3,000 rpm, 1 min）した. Oasis ${ }^{\circledR}$ HLB を添加したマイク ロチューブを@ろ過 ${ }^{\mathrm{TM}}$ から脱着し，擋拌・分散し て, $100 \mathrm{mg} / \mathrm{mL}$ の固相懸濁液を調製した.

\section{4 試料前処理}

\section{4-1 血清の除タンパク}

各試験対象 7 物質 $(250 \mathrm{ng} / \mathrm{mL})$ を添加した血清 またはブランク血清 $0.5 \mathrm{~mL}$ をマイクロチューブに 入れ，アセトニトリル $0.5 \mathrm{~mL}$ を加えて擋拌し，遠 心分離 (10 krpm, $1 \mathrm{~min})$ した。 上清を可能な限り 採取し, 窒素気流下, $40^{\circ} \mathrm{C}$ で約 $0.25 \mathrm{~mL}$ まで濃縮 し, 濃縮液を以下のと抢り固相分散抽出した.

\section{4-2 SPDE による前処理操作}

@ ろ過 ${ }^{\mathrm{TM}}$ の上部にキャップチューブTM, 下部に マイクロチューブを装着し, キャップチューブTM 側に上記のとおり除タンパク処理をした添加血清ま たはブランク血清 $0.25 \mathrm{~mL}$ および固相懸濁液 $0.1 \mathrm{~mL}$ 
（固相剤10 mg 相当）を添加した。ボルテックスミ キサーで擋拌し，遠心分離（3,000 rpm, $1 \mathrm{~min} ） し$ た後，ろ液が入ったマイクロチューブを外し，代わ って新たに空のマイクロチューブを@ろ過 $\mathrm{TM} に$ 装 着して, キャップチューブTM側に超純水 $1.0 \mathrm{~mL}$ を 加えて擋拌し，遠心分離 $(3,000 \mathrm{rpm}, 1 \mathrm{~min} \times 2)$ し て固相を洗浄した. 洗液の入ったマイクロチューブ を外し, 空のマイクロチューブに再度交換し, 溶出 溶媒としてアセトン $1.0 \mathrm{~mL}$ を加えて擋汼し, 更に 超音波照射 $(100 \mathrm{kHz}, 1 \mathrm{~min})$ した後, 同様に遠心 分離 $(3,000 \mathrm{rpm}, 1 \mathrm{~min})$ した。溶出液は, 圧縮気 流下で蒸発乾固し, メタノール $0.5 \mathrm{~mL}$ で再溶解さ せ, 遠心分離 (10 krpm, $1 \mathrm{~min}) し$, 上清を GC/ MS 用試験溶液とした.

\section{GC/MS 条件検討}

GC/MS に抢いては，高感度かつ選択性の高い SIM モードを選択し， GC キャピラリーカラム， オーブンの昇温温度条件については, 国連薬物犯罪 事務所が推奨する合成カンナビノイドの分析法 ${ }^{16)}$ に 準じて至適条件を検討し, 次の条件とした。

装置：Agilent 社製7890A GC/5975C MSD

分析力ラム : Agilent 社製 DB-5MS $(30 \mathrm{~m} \times 0.25$ $\mathrm{mm}$ i.d, 膜厚 $0.25 \mu \mathrm{m}$ )

注入口温度 : $250^{\circ} \mathrm{C}$

カラム温度 : $180^{\circ} \mathrm{C}(1 \mathrm{~min}$ 保持 $)-5^{\circ} \mathrm{C} / \mathrm{min}$ 昇 温 $-250^{\circ} \mathrm{C}$ ( $5 \min$ 保持 $)-20^{\circ} \mathrm{C} /$ $\min$ 昇温 $-310^{\circ} \mathrm{C}(7 \mathrm{~min}$ 保持)

トランスファーライン温度 : $280^{\circ} \mathrm{C}$

注入量 : $2 \mu \mathrm{L}$

注入法 : スプリットレス

キャリアーガス :ヘリウム $(1.2 \mathrm{~mL} / \mathrm{min})$

イオン化法 : 電子イオン化法 $(\mathrm{EI})$

イオン化電圧 : $70 \mathrm{eV}$

イオン源温度 : $280^{\circ} \mathrm{C}$

四重極温度 : $150^{\circ} \mathrm{C}$

測定方法 : SIM

$\mathrm{JWH}-018$ ：測定用イオン $\mathrm{m} / \mathrm{z} 214$, 確認用イ オン $\mathrm{m} / \mathrm{z} 341$

$\mathrm{JWH}-122$ ：測定用イオン $\mathrm{m} / \mathrm{z} 214$ ，確認用イ オン $\mathrm{m} / \mathrm{z} 355$

JWH-073：測定用イオン $\mathrm{m} / \mathrm{z} 200$, 確認用イ
オン $\mathrm{m} / \mathrm{z} 327$

$\mathrm{CCH}$ : 測定用イオン $\mathrm{m} / \mathrm{z} 233$, 確認用イオン $\mathrm{m} / \mathrm{z} 314$

XLR-11：測定用イオン $\mathrm{m} / \mathrm{z} 232$, 確認用イオ ソ $\mathrm{m} / \mathrm{z} 314$

$\mathrm{AM} 2201$ : 測定用イオン $\mathrm{m} / \mathrm{z} 232$, 確認用イオ ソ $\mathrm{m} / \mathrm{z} 359$

MAM-2201 : 測定用イオン $\mathrm{m} / \mathrm{z} 373$, 確認用イ オン $\mathrm{m} / \mathrm{z} 232$

\section{6 分析法バリデーションの検討}

検出限界, 定量限界抢よび検量線は, 試料注入時 のサンプルマトリックスの影響を補正するためマト リックスマッチング法により測定を行った。予め合 成カンナビノイドが検出されないことを確認した血 清をブランク試料とし，「4 試料前処理」のとおり 前処理を行った．溶出液を蒸発乾固した残留物に $2.5,5,10,25,100,250,500 \mathrm{ng} / \mathrm{mL}$ の濃度に調製し た各合成カンナビノイドのメタノール溶液 $0.5 \mathrm{~mL}$ を添加し， GC/MS を行った $(\mathrm{n}=3)$. な拈，定量 方法は絶対検量線法により行った.

真度抢よび精度は，各合成カンナビノイドを 25 $\mathrm{ng} / \mathrm{mL}$ および $450 \mathrm{ng} / \mathrm{mL}$ に調製した血清を用い， 1 日に 2 回, 計 5 日の添加回収試験を行い評価した. 添加回収試験は調製した血清を「4 試料前処理」 のと抢り前処理を行い, GC/MS を行った $(n=3)$. 添加回收試験から得られた各濃度の回収率から, 真 度については平均回収率で, 精度については併行精 度および室内精度を一元配置分散分析により相対標 準偏差（RSD）を算出し評価した.

\section{結果および考察 \\ 1 SPDE $の$ 最適操作条件}

\section{1-1 固相凧の確認}

Oasis ${ }^{\circledR}$ HLB は，親水性・親油性基を併せ持つ逆 相固相で, 酸性, 塩基性, 中性全ての化合物に対応 できる固相剂であるが，同カートリッジを用いた SPE による血清中合成カンナビノイド類の抽出は 既に検討され，その有用性は確認されている15)こと から，本研究では固相剂として Oasis ${ }^{\circledR}$ HLB を選択 した。

各試料に Oasis ${ }^{\circledR}$ HLB の固相懸濁液を添加し，ボ 
ルテックスミキサーで擋汼，遠心分離した後，上澄 を測定した結果，対象物質の合成カンナビノイドが 検出されなかったことから，すべて固相に試料の合 成カンナビノイドが保持されたことを確認した。

\section{1-2 溶出溶媒の選定}

測定対象物質（7 種類）に対する溶出溶媒として は，アセトン， $2 \%$ ギ酸/酢酸エチル溶液，酢酸エチ ル，アセトニトリルおよびメタノールのそれぞれ極 性の異なる有機溶媒を選択し，比較検討をおこなっ た.

その結果，各物質に対する回収率は，アセトン， $2 \%$ ギ酸/酢酸エチル溶液では，各物質とも概ね $80-$ 100\%と良好な回収率が得られたが，酢酸エチル， アセトニトリルおよびメタノールによる回収率は, 40-70\%程度と低い值であった（Fig. 3)。このこと から，測定対象物質は Oasis ${ }^{\circledR}$ HLB に対して疎水性 相互作用としての保持が強く, また, 弱いながらも イオン交換相互作用の存在も推察されたことから, アセトンおよび $2 \%$ ギ酸/酢酸エチル溶液が効率の 良い溶出溶媒であることが示唆された。溶媒につい ては， $2 \%$ ギ酸/酢酸エチル溶液を用いた場合，溶媒 の調製や溶出液濃縮・乾固の作業に時間がかかった のに対し，アセトンの方が作業時間を短縮できるこ とから，アセトンを溶出溶媒として選定した.
なお SPEでは，酢酸エチルによる溶出が最も効 率的でその回収率は $90 \%$ 以上であると報告がある が15)，これはSPEでは，カラムクロマトグラフ ィーの原理にしたがって動的に溶出しているのに対 して，SPDEについては，分散現象に基づく固相と 液相との分配平衡によって静的に溶出している，と いうメカニズムの違いがあったためと考えられる.

\section{1-3 固相剤添加量の比較}

通常の $1 \mathrm{~mL}$ 程度の液体試料を処理する際に使わ れるSPEにおいて, カートリッジに充填されてい る固相剤の量は $30 \mathrm{mg}$ であることから, 本実験で は, 固相剤の至適添加量を確認するため, 5, 10, 20, 30 および40 mg について回収率を比較検討した.

その結果, いずれの場合においても60\%以上の回 収率が得られ, 固相剤の量に対する回収率の明確な 変動は認められなかったが, $10 \mathrm{mg}$ の固相剤を添加 したときの回収率は80-100\% と最も高い回収率を示 した（Fig. 4).これは固相剤の添加は $5 \mathrm{mg}$ では不 十分であったが, $10 \mathrm{mg}$ で必要十分量であることが 示され, 更に $20 \mathrm{mg}$ 以上では固相剤が過剰となって 溶出が不十分になり, 回収量が減少したものと考え られ，固相剤の添加量としては $10 \mathrm{mg}$ を選択した。

\section{1-4 SPDEの操作性}

従来のSPE との操作性を比較するため, Oasis ${ }^{\circledR}$

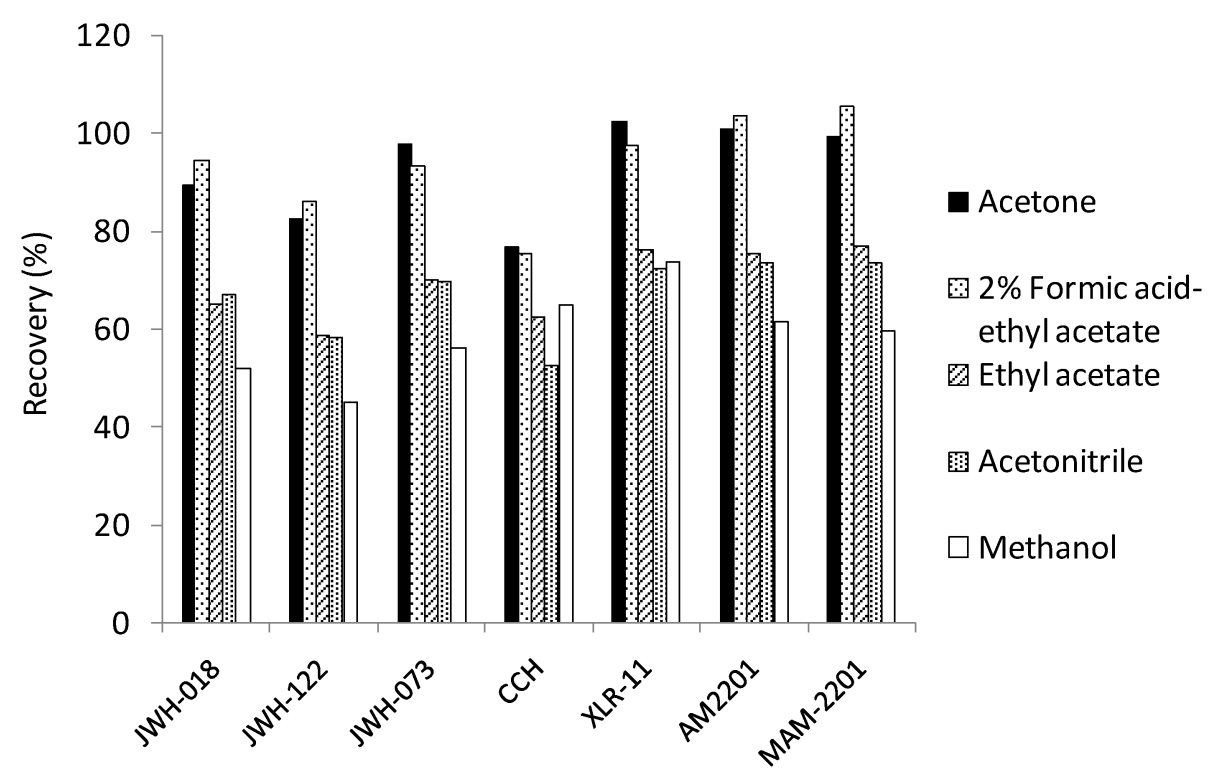

Fig. 3 Comparison of eluents in terms of recovery of seven synthetic cannabinoids. 




Fig. 4 Comparison of amounts of seven synthetic cannabinoids recovered from each solid-phase gel.

HLB が充填された市販のカートリッジを使用して 抽出処理を行った場合, 試料添加から溶出まで約 30 分間を要するのに対し, SPDEの処理時間は, 約 10 分以内に迅速に処理することができた。 また，カー トリッジを使用した場合, 溶出速度を約 $1 \mathrm{~mL} / \mathrm{min}$ に調整して行う必要があり, 試料の粘性によって, カートリッジからの溶出速度を一定に保つために, 試料負荷・洗浄・溶出に際して, 常にマニホールド 内の圧力調整を行わなければならなかったが， SPDE では固相を試料中で分散させた際, 瞬時に固 相と液相間での薬物の分配が平衡に達し, 試料前処 理時に, ボルテックスミキサー撹拌後, 遠心ろ過フ ィルターを用いて遠心分離により固相と液相を分離 するだけで処理を終了することができた。また， SPDE では複数の試料を全て同時に遠心分離で処理 することができるため, SPEのような操作の煩雑 性はほとんどなかった。

\section{2 定量方法（マトリックスマッチング法）}

MS を用いた定量方法では, 一般に重水素ラベル 体や ${ }^{13} \mathrm{C}$ ラベル体を用いた，いわゆる同位体希釈質 量分析法に基づく内部標準法により実施されるが， 麻薬として指定される合成カンナビノイドの重水素 ラベル体の入手は困難であり，またサロゲートとし て同じ挙動を示す構造類似体を選択できなかったこ とから, 本研究は絶対検量線法での定量を検討し た。なお，試料にかかる GC/MSの際，マトリッ
クス由来の妨害が認められたことから，これを補正 するため, 試料溶液と同等のマトリックスで標準溶 液を作成し，検量線を作成するマトリックスマッチ ング法で定量を行った。

\section{GC/MS 結果}

$\mathrm{GC} / \mathrm{MS}$ の結果, 各測定対象物質のピーク形状は 良好であり，いずれも良好に相互分離された。 XLR-11については, GC/MS の際, 熱分解される ことが報告されているが17)，本測定に打いても XLR-11分解物の出現を確認した (Fig. 5). なお, 測定用イオンが重複する場合であっても, 確認用イ オンが異なるため, 判別は十分に可能であった (Fig. 6).

次に, 実試料として血清に各合成カンナビノイド 標準品を添加して500 ng/mLの濃度に調製したも のについて本法に従って前処理を行い， GC/MS を 行った. その結果, 血清のマトリックス由来の夾雑 物による妨害ピークの影響は見られず，7種類の測 定対象物質は良好に定性・定量分析できることが確 認された。なお XLR-11については，すべての測定 結果に抢いて，XLR-11の分解の割合は，29.0\% (SD : $0.9 \%)$ であり, 全試料が同じ分解の挙動を 示すことが確認できたため, 分解物については考慮 せず，XLR-11の測定結果のみを用いて定量分析を 行った. 

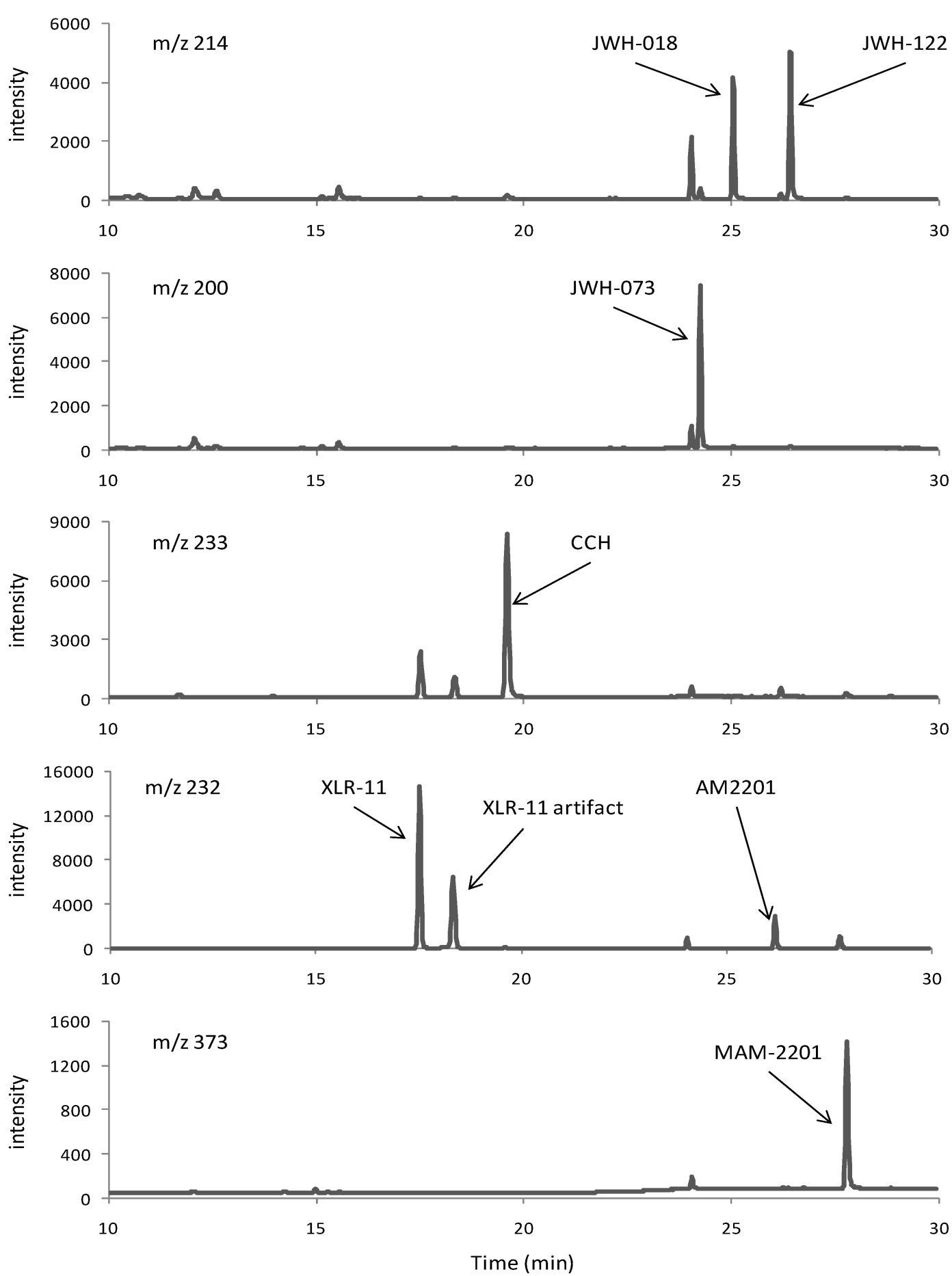

Fig. 5 Chromatograms of target ions of seven synthetic cannabinoids in serum spiked with $250 \mathrm{ng} / \mathrm{mL}$ synthetic cannabinoid standards.

4 分析法バリデーション

4-1 検出限界, 定量下限および検量線

マトリックスマッチング法により測定を行ったと ころ，各物質の検出限界（S/N>3）および定量下
限（S/N>10）を算出した結果，検出限界は， 2.5 および $5.0 \mathrm{ng} / \mathrm{mL}$ ，定量下限は，5.0および $10 \mathrm{ng} /$ $\mathrm{mL}$ であった。 また，検量線は 5〜 500 ng/mL およ び10〜 $500 \mathrm{ng} / \mathrm{mL}$ の濃度範囲で良好な直線性（相 



Fig. 6 Chromatograms of the qualifier ions of seven synthetic cannabinoids in serum spiked with $250 \mathrm{ng} / \mathrm{mL}$ synthetic cannabinoid standards. 
関係数 $r=0.994 \sim 0.999 ）$ を示した（Table 1）.

なお定量下限以下である $1.0 \mathrm{ng} / \mathrm{mL}$ の各試料 0.5 $\mathrm{mL}$ を窒素気流下で乾固し, メタノール $0.05 \mathrm{~mL}$ に 溶解して測定を行ったところ，各物質とも定量下限 （S/N>10）以上の結果が得られたことから，更な る高感度分析が要求された場合でも，その対応は可 能であることが確認された。

\section{4-2 添加回収試験（真度および精度）}

平均回収率は，低濃度では76.9-107.4\%（SD： 6.4-10.7\%)，高濃度では63.1-89.6\%（SD : 3.9-8.2 \%) となり，真度は良好であった。各精度の許容限 度はShah らの報告 ${ }^{18)}$ に準じて，低濃度では「ミ20

Table 1 Limits of detection (LOD), limits of quantitation (LOQ), and calibration ranges of all analytes.

\begin{tabular}{lcrrc}
\hline Analyte & $\begin{array}{c}\text { LOD } \\
(\mathrm{ng} / \mathrm{mL})\end{array}$ & $\begin{array}{c}\text { LOQ } \\
(\mathrm{ng} / \mathrm{mL})\end{array}$ & $\begin{array}{c}\text { Calibration } \\
\text { range } \\
(\mathrm{ng} / \mathrm{mL})\end{array}$ & $\begin{array}{c}\text { Correlation } \\
\text { coefficient } \\
(\mathrm{r})(n=5)\end{array}$ \\
\hline JWH-018 & 2.5 & 5.0 & $5-500$ & 0.997 \\
JWH-122 & 2.5 & 5.0 & $5-500$ & 0.994 \\
JWH-073 & 5.0 & 10.0 & $10-500$ & 0.997 \\
CCH & 2.5 & 5.0 & $5-500$ & 0.999 \\
XLR-11 & 2.5 & 5.0 & $5-500$ & 0.998 \\
AM2201 & 2.5 & 5.0 & $5-500$ & 0.996 \\
MAM-2201 & 5.0 & 10.0 & $10-500$ & 0.996 \\
\hline
\end{tabular}


行精度および室内精度を一元配置分散分析により相 対標準偏差（RSD）を算出し評価した結果, 精度 も低濃度抢よび高濃度共に許容限度内に収まること が確認された（Table 2).

\section{結 語}

薬物乱用が HIV 感染の主要な経路の 1 つになっ ていることは論を待たないところであるが19), 薬物 乱用者の血液を分析する際, 感染予防には十二分に 留意するよう心掛けなければならない，従来の SPEで使用するマニホールドのような開放系の器 具では, 分析後, 拡散した血液等の生体試料の処理 に考慮しなければならないが，SPDE は血液試料を ほぼ閉鎖系で処理することができるため，操作中に おける血液試料の飛散などによる実験者への曝露を 低減できる前処理法であると言える.

従来, LC/MS での合成カンナビノイドの血中未 変化体の検出事例は打よそ0.1〜230 ng/mL と報告 されている11,12). 本研究で構築した SPDE-GC/MS 法による定量下限は， $5.0 \sim 10 \mathrm{ng} / \mathrm{mL}$ であるが，低 レベルに扔いて LC/MS 等と同等の感度で行う必要 があれば，試料を濃縮することにより，同等レベル の分析も可能となる.

Table 2 Accuracy and precision of detection of all analytes.

\begin{tabular}{lcccc}
\hline \multirow{2}{*}{ Analyte } & \multirow{2}{*}{$\begin{array}{c}\text { Concentration } \\
(\mathrm{ng} / \mathrm{mL})\end{array}$} & $\begin{array}{c}\text { Recovery } \\
(\%)\end{array}$ & Intra-assay precision & Intermediate precision \\
\cline { 4 - 5 } JWH-018 & 25 & $99.8 \pm 9.4$ & 2.38 & 9.95 \\
JWH-122 & 25 & $107.4 \pm 6.4$ & 4.11 & 6.19 \\
JWH-073 & 25 & $97.0 \pm 8.7$ & 8.60 & 6.19 \\
CCH & 25 & $76.9 \pm 10.7$ & 8.95 & 14.46 \\
XLR-11 & 25 & $95.0 \pm 9.0$ & 3.39 & 9.93 \\
AM2201 & 25 & $104.2 \pm 6.4$ & 1.72 & 6.44 \\
MAM-2201 & 25 & $99.0 \pm 9.0$ & 3.61 & 9.57 \\
\hline JWH-018 & 450 & $78.3 \pm 3.9$ & 2.33 & 5.23 \\
JWH-122 & 450 & $71.9 \pm 5.2$ & 5.26 & 10.61 \\
JWH-073 & 450 & $81.7 \pm 4.3$ & 10.21 & 10.64 \\
CCH & 450 & $63.1 \pm 6.3$ & 5.56 & 6.46 \\
XLR-11 & 450 & $87.0 \pm 4.9$ & 3.05 & 6.09 \\
AM2201 & 450 & $89.6 \pm 5.5$ & 5.02 & 9.31 \\
MAM-2201 & 450 & $85.4 \pm 8.2$ & 6.27 & \\
\hline
\end{tabular}


以上 SPDE-GC/MS 法は, 簡便, 迅速, かつ精 度の高い分析法であり, 対象とした麻薬である合成 カンナビノイド 7 品目の血中未変化体の確認試験法 として有用であることが示唆された.

\section{謝 辞}

本研究は, 厚生労働科学研究費補助金（医薬品· 医療機器等レギュラトリーサイエンス総合研究事 業，H25-医薬一一般-019）の助成により行われたも ので，関係各位に深謝する.

\section{文 献}

1）花尻（木倉）瑠理, 脱法ドラッグ（脱法ハー ブ)”による健康被害を防ぐために。 日本法科学 技術学会誌, 18別冊, 1, 2013.

2) UNODC, The challenge of new psychoactive substances. United Nation Publication, p. 3, Vienna, 2013.

3）厚生労働省医薬食品局監視指導 · 麻薬対策 課 : 第 8 章合成ハーブ等と称して販売される薬 物（いわゆる脱法ドラッグ）対策. 麻薬・覚醒 剂行政の概況, pp. 201-203, 2013.

4) Hutter, M., Broecker, S., Kneisel, S. and Auwärter, V., Identification of the major urinary metabolites in man of seven synthetic cannabinoids of the aminoalklindole type present as adulterants in 'herbal mixures' using LC-MS/MS techniques. J. Mass. Spectrom., 47, 54-65, 2012.

5) Sobolevsky, T., Prasolov, I. and Rodchenkov, G., Detection of JWH-018 metabolites in smoking mixture post-administration urine. Forensic Sci. Int., 200, 141-147, 2010.

6) Teske, J., Weller, JP., Fieguth, A., Rothämel, T., Schulzlr, Y. and Tröger, HD., Sensitive and rapid quantification of the cannabinoid receptor agonist naphthalen-1-yl-(1-pentylindol-3-yl) methanone (JWH-018) in human serum by liquid chromatography-tandem mass spectrometry. $J$. Chromatogr. B, 878, 2659-2663, 2010.

7) Kneisel, S. and Auwärter. V., Analysis of 30 synthetic cannabiniods in serum by liquid chro- matography-electrospray ionization tandem mass spectrometry after liquid-liquid extraction. $J$. Mass. Spectrom., 47, 825-835, 2012.

8) Zhang, L., Wang, Z-H., Li, H., Liu, Y., Zhao, M., Jiang, Y. and Zhao, W-S., Simultaneous determination of 12 illicit drugs in whole blood and urine by soild phase extraction and UPLC-MS/ MS. J. Chromatogr. B, 955-956, 10-19, 2014.

9) Ammann, J., Mclaren, J., Gerostamoulos, D. and Beyer, J., Detection and Quantification of New Designer Drugs in Human Blood: Part1Synthetic Cannabioids. J. Anal. Toxicol., 36, 372-380, 2012.

10) Shanks, K. G., Dahn, T. and Terrell, A. R., Detection of JWH-018 and JWH-073 by UPLCMS/MS in Postmortem Whole Blood Casework. J. Anal. Toxicol. 36, 145-152, 2012.

11) Hermanns-Clausen, M., Kneisel, S., Hutter, M., Szabo, B. and Auwärter, V., Acute intoxication by synthetic cannabinoids-Four case reports. Drug Test Analysis, 2013.

12) SWGDRUG, RECOMMENDATIONS (METHOD OF ANALYSIS/DRUG IDENTIFICATION) p. 14, July-7, 2011.

13) Saito, K., Kikuchi, Y. and Saito, R., Solidphase dispersive extraction method for analysis of benzodiazepine drugs in serum and urine samples. J. Pharm. Biomed. Anal., 100, 28-32, 2014.

14) Sakamoto, Y., Jinno, Y. Shinodzuka, I., Iwasaki, Y., Ito, R. and Saito, K., Sample Cleanup Using Solid-Phase Dispersive Extraction for Determination of Vancomycin in Serum. Anal. Sci., 30, 271-275, 2014.

15）嘉数一路, 久恒一晃, 石場 厚, 松本智寛, 血清中合成カンナビノイド類の抽出方法の検 討. 日本法科学技術学会誌, 18 別冊, 44, 2013.

16) UNODC, Recommended method for the Identification and Analysis of Synthetic Cannabinoid Receptor Agonists in Seized Materials. p. 34, United Nation, New York, 2013.

17) Choi H., Heo S., Kim E., Hwang B., Lee C. 
and Lee J., Identification of (1-pentylindol-3-yl)(2,2,3,3-tetramethylcyclopropyl) methanone and its 5-pentyl fluorinated analog in herbal incense seized for drug trafficking. Forensic Toxicol., 31, 86-92, 2013.

18) Shah V., Midha K., Findlay J., Hill H., Hulse J., McGilveray I., McKay G., Miller K., Patnaik
R., Powell M., Tonelli A., Viswanathan C. and Yacobi A., Bioanalytical Method Validation-A Revisit with a Decade of Progress. Parm. Res., 17, 1551-1557, 2000.

19）和田 清, 小堀栄子, 薬物依存と $\mathrm{HIV} / \mathrm{HCV}$ 感染一現状と対策一. J. AIDS Research, 1, 1-7, 2011. 